\title{
Our Surgical Heritage: The Legends of Exposure
}

\author{
Rao R Ivatury
}

\author{
Abstract \\ Aim: Pay homage to three of the eminent creators of surgical retractors. \\ Materials and Methods: Literature review. \\ Background: Good exposure is the key to good surgery and all successful operations. Hand-held and self-retaining retractors are so essential \\ for exposure that we use them every day. Hardly ever, though, the innovators of these indispensable tools receive a second thought. \\ Clinical significance: Surgical heritage review. \\ Clinical relevance: Surgical heritage. \\ Keywords: Balfour, Bookwalter, Finochietto, Laparotomy retractors, Retractors, Surgical exposure, Surgical tools, Thoracotomy retractors.
}

\section{Resumen}

Objetivo: rendir homenaje a tres de los eminentes creadores de retractores quirúrgicos.

Materiales y métodos: revisión de la literatura Fondo ; Una buena exposición es la clave para una buena cirugía y todas las operaciones exitosas. Los retractores manuales y autorretenedores son tan esenciales para la exposición que los usamos todos los días. Casi nunca, sin embargo, los innovadores de estas herramientas indispensables reciben un segundo pensamiento.

Importancia clínica: revisión del patrimonio quirúrgico.

Palabras clave: Balfour, Bookwalter, Finochietto, Retractores de laparotomía, Retractores, Exposición quirúrgica, Instrumentos quirúrgicos, Retractores toracotomia.

Panamerican Journal of Trauma, Critical Care \& Emergency Surgery (2021): 10.5005/jp-journals-10030-1303

\section{INTRODUCTION}

The unique charm of a career in trauma surgery is the opportunity to operate in almost any region of the body. A trauma surgeon's procedure log may include a neck dissection, thoracotomy, laparotomy, and extremity vessel exploration, all on the same day. Equally exciting is the variety: thoracic and abdominal organ repairs, vascular reconstruction, bowel resection, and treatment of injuries to nerves, tendons, and bones, among others.

All of these operations have a common theme: a vivid exposure of the organ(s) of interest. "Good exposure is the key to good surgery" is an oft-repeated precept from surgical teachers. Retraction is the key to good exposure. As the art of trauma surgery has evolved, so have the tools and instruments used to aid the surgeon. The first known surgical instruments were described by the Indian surgeon-healer, Sushruta, (approximately 500 BC), often considered the "father of surgery". Hippocrates (approximately 400 BC) reportedly developed more than 200 different surgical instruments. ${ }^{1}$ These tools are so essential and indispensable to the craft that we use them every day, often naming them by their creators. Hardly ever, though, we give these names a second thought. Consider, e.g., a trauma laparotomy: a few minutes into the operation, one hears a request for a "Richardson" or a "Deaver", even a "sweet-heart (Harrington)". Very soon, the call is made for the self-retaining variety, much to the relief of the belabored junior assistant!

This report aims to pay homage to three eminent innovators of exposure: for thoracotomy (Finochietto) ${ }^{1-11}$ or laparotomy (Balfour $^{12-22}$ and Bookwalter ${ }^{23-29}$ ).
Department of Surgery, Virginia Commonwealth University, Richmond, Virginia, USA

Corresponding Author: Rao R Ivatury, Department of Surgery, Virginia Commonwealth University, Richmond, Virginia, USA, Phone: +804 651 1574, e-mail: raoivatury@gmail.com

How to cite this article: Ivatury RR. Our Surgical Heritage: The Legends of Exposure. Panam J Trauma Crit Care Emerg Surg 2021;10(1):3-7.

Source of support: Nil

Conflict of interest: None

\section{Enrique Finochietto (1881-1948)}

Enrique Finochietto ${ }^{1-6,8-10}$ (Fig. 1A) was the oldest son of two immigrants to Argentina from Genoa, Italy. He was born on March 1881. Sadly, his father died when he was very young and his mother brought up the children with a good education. At the age of 16 , he entered the University of Buenos Aires School of Medicine and graduated with honors 4 years later. Soon he became fascinated by the surgeon Alejandro Posadas in the Clinicas Hospital. ${ }^{7}$ Posadas was one of the most famous Argentinian surgeons, he systematized techniques and concepts of his time with reports of patient series. Unusual for the time, he would use detailed presentations with illustrations, photographs, and movies. Finochietto blossomed under his wing and soon was named as a permanent staff member at the Rawson Hospital in Buenos Aires. His internship was grueling, unpaid work with no breaks or holidays. Under Posadas and later with Marcelino Herrera Vegas, another prominent surgeon,

\footnotetext{
(c) The Author(s). 2021 Open Access This article is distributed under the terms of the Creative Commons Attribution 4.0 International License (https:// creativecommons.org/licenses/by-nc/4.0/), which permits unrestricted use, distribution, and non-commercial reproduction in any medium, provided you give appropriate credit to the original author(s) and the source, provide a link to the Creative Commons license, and indicate if changes were made. The Creative Commons Public Domain Dedication waiver (http://creativecommons.org/publicdomain/zero/1.0/) applies to the data made available in this article, unless otherwise stated.
} 

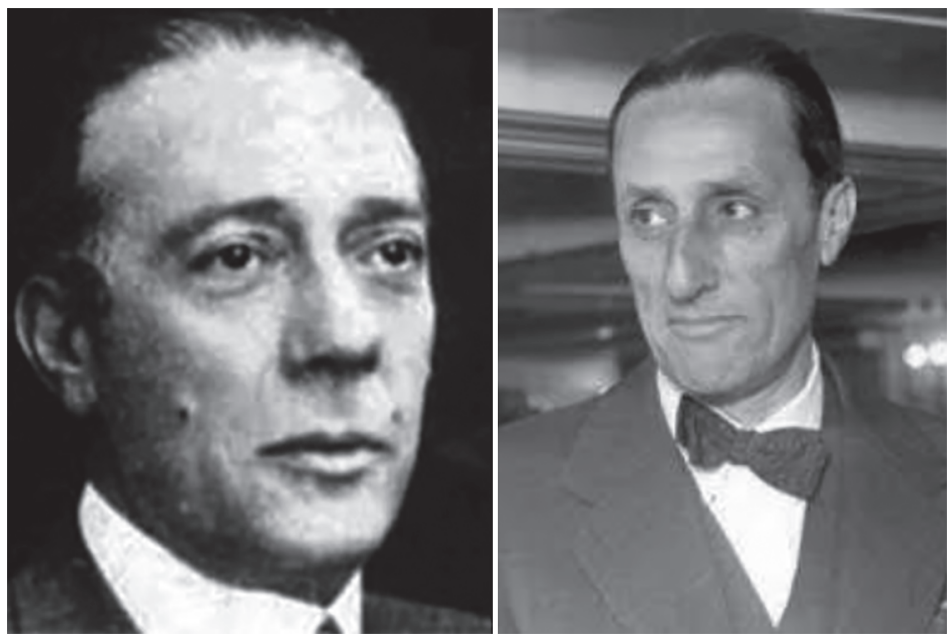

Figs $1 \mathrm{~A}$ and $\mathrm{B}$ : (A) Enrique Finochietto; (B) Ricardo Finochietto

Finochietto learned science and culture. He received his medical degree in 1904, at 23 years of age. ${ }^{2-6}$

In 1906, he traveled to Europe for clinical and artistic experience. For 3 years, he studied under French, German, and Austrian teachers as well as Italian and Swiss surgeons. He also visited cathedrals and art galleries. In 1909, he returned from Europe to his beloved Rawson Hospital. In 1914, when he was only 33, he became Chief of Surgery. With the help of his brother Ricardo (Fig. 1B), he rapidly began to implement the knowledge he gained in Europe. He equipped his service with the most advanced technologies available at the time. He instituted the concept of exquisitely detailed operative reports with elaborate diagrams of the technical steps. These were later compiled into a surgical atlas. ${ }^{2-6}$

In 1918, Finochietto traveled to France during World War I (WWI) to join the Argentine Hospital in Passy as a surgeon-in-chief. Here, he interacted with great surgeons like Gosset, Duval, and Leriche and produced a thesis on "Treatment of war injuries and transportation of the wounded patient". He was honored with the "Legion D'Honneur", the gold medal of war, and the Red Cross medal for his services to the wounded. ${ }^{2-6,8}$

\section{The Man and His Innovations}

His disciple Uriburu described him: "His arms were thin, apparently without muscles, typical of the person who has not been affected by sports. However, he had an unsuspected strength, especially when he handled the famous left hand. His physical resistance was prodigious". ${ }^{6}$ Adrian Jacobo Bengolea, a senator of the legislature of the province of Buenos Aires, expressed: "Silence was the usual air for Enrique Finochietto and also his means of teaching, his way of applauding a success or correcting a mistake. He preferred silence, accuracy, measure, and perhaps these were the most prodigious qualities of his miraculous learning". ${ }^{6}$ Fairman ${ }^{8}$ described him as "Modest and unassuming, he never obtruded his personality or exploited his merits or achievements as claim for priority, but rather referred to himself in an impersonal way, and allowed the facts to speak for themselves".

Finochietto was also an avid reader. He had a huge library with thousands of volumes in Spanish, English, German, Italian, and French; he could read and speak all of these languages well. ${ }^{4-6}$ With the collaborative efforts of his younger brother Ricardo and others, he created numerous new surgical devices, from endoscopic apparatuses to operating tables; "frontolux" (surgical headlight),

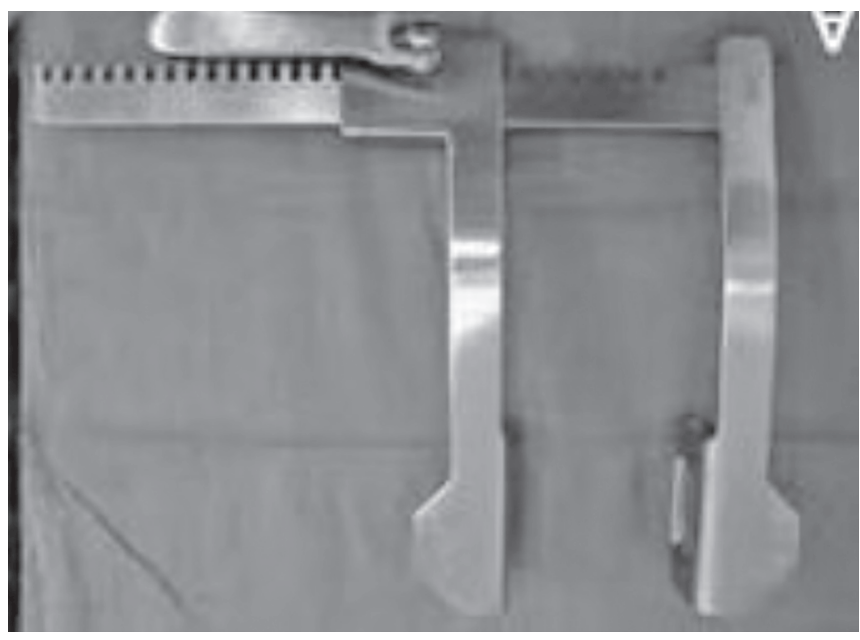

Fig. 2: The Finochietto retractor

"ligature pusher"; needle holder in various sizes and formats; hemostatic forceps; surgical aspirator to clean the blood from the operative field, cannula for transfusions, a mobile surgical table operated with pedals and driven by an electric motor, a bench for surgeons to allow operating while seated; and, of course, the famous zippered intercostal retractor for chest operations, universally known as the "Finochietto retractor" (Fig. 2) (called "the ambassador" by his brother, Ricardo), ${ }^{2-6,8}$ in different sizes for adults and children. In his characteristic humble style, he introduced his famous retractor in 1941 thus: "For the last 4 years, we have been using this thoracic retractor with parallel arms which opens, thanks to an irreversible. ..$^{3}$

\section{A Pioneering Surgeon}

On his return from France, Enrique found the Rawson Clinic being demolished. He grabbed the opportunity to redesign a new "surgical pavilion" with modern operating rooms and a new powered surgical operating table. Antiseptic protocols were introduced. A new outpatient department, separate departments of Orthopedic Surgery, Endoscopy, Otorhinolaryngology, Pathology, Laboratories, and Radiology were created. The young surgeon remarkably foresaw the contributions that an internist can make to the surgical team. 
Surgical leader ${ }^{2-6,8}:$ Enrique Finochietto's surgical abilities were not restricted to a few areas. He was into orthopedics, developing a technique for bone transfixion and traction, similar to the Kirschner Wire. He developed a special orthopedic table. He wrote a treatise on the treatment of brain tumors and was the first surgeon in Argentina to successfully excise a ganglioneuroma. He started the department of Thoracic Surgery and created Plastic Surgery as a separate service. In 1929, he performed the first operation for a cardiac tamponade due to a stab wound of the heart. In addition, he worked extensively in gastrointestinal, colonic, and rectal surgery.

As a surgeon, he was slow, deliberate, and meticulous, emphasizing precision, the economy of movement, and exquisite rhythm over speed. He would berate the prevailing love for flamboyance and haste. In his own words: "You should start operations right to finish them right... the most important aspect of (surgeon's) life is the mental integration of the innumerable details which constitute a perfect operation.... After a determinate amount of time this tune up is finished and the surgeon can visualize the operation in minute detail with complete clarity, as a painter should see a painting before he starts". ${ }^{3}$

\section{Creator of "Surgical School"5}

Enrique Finochietto is often recognized as the creator of a "surgical school" in South America. As he was building his new department, he was dissatisfied with the lack of an organized, progressive delegation of responsibility. Trainees were not being permitted to perform major surgery. To overcome this, he began by standardizing every specific technique for each surgical procedure. He soon acquired a large database of drawings, photographs, and radiographic films organized in a detailed fashion. He would use these to improve the existing, pathetic medical record in use. These modifications assisted his team to follow his approach to patient care and learn from it.

In the field of surgery, he was known as "The Divine". ${ }^{5}$ The sign at the entrance of the operating theater number IX at the old Rawson Hospital: “Enrique Finochietto operated and taught in this place $^{\prime \prime}$ is a testimonial to his eminence. Other great figures paid him handsome tribute: Leriche, in his book La Philosophic de la Chirurgie in 1951, said of Finochietto: "Some exceptional surgeons create instruments.... There are some great creators. The three greatest surgeons of this class that I have known are: Jaboulay, E. Finochietto, and W. Dandy". Lord Moyniham, President of the Royal College of Surgeons of England, said after witnessing Dr Finochietto operate: "If ever I have to be submitted to the knife, let it be by this extraordinary surgeon called Enrique Finochietto." ${ }^{2-5}$

Buenos Aires loved the surgical master. A street in the city was named after him. The Hospital San Martín de La Plata (HIGA) has a surgical pavilion named after him. A clinic in the Recoleta neighborhood of Buenos Aires bears his name. A residential building where Finochietto once resided was declared a historic site and bears a plaque with his name. ${ }^{2}$

One last anecdote to memorialize Enrique Finochietto: Enrique was in the habit of frequenting Buenos Aires Cabaret at night after his busy day of surgery. One night in 1924, he was having dinner with his friends in the sumptuous Chantecler cabaret. The conductor of the orchestra Julio De Caro (a famous violinist of the time) came down from the stage, violin in hand, approached the table slowly and respectfully and, turning to Finochietto, he said, "Doctor Finochietto, that young man you see sad and crying has been told that his wife will die tonight from a serious abdominal disease". "Don't worry, friend", replied the doctor, "Let us go see that lady". That same night, almost at dawn, he operated and saved the patient and took care of all the expenses. On hearing this, De Caro composed a "tango" and dedicated it to the doctor with the name: Buen amigo (Good friend). 4,6,10

Finochietto performed his last masterful operation to remove a hydatid cyst on March 8, 1940. On March 19, 1947, he suffered a cerebral episode related to his exposure to syphilis while in France. He died on February 17, 1948, at the age of $66 .^{1-6,8} \mathrm{Dr}$ Michael DeBakey, in his obituary ${ }^{9}$ wrote: "His passing represents an irretrievable loss to the medical profession ....because a brilliant and inquiring mind has been silenced forever......".

A few notes about Enrique's younger brother and lifelong partner, Ricardo who was also into surgical education. ${ }^{3,8} \mathrm{He}$ implemented the system of residency in Argentina by establishing a surgical school specifically for recent graduates to improve their technique. In 1950, he was designated as Eva Perón's head physician and was in attendance when U.S. surgeon George Pack performed a hysterectomy on her. He died in 1962.

\section{Donald Balfour (1882-1963) ${ }^{12-22}$}

Donald Balfour (Fig. 3) was the inventor of the self-retaining abdominal retractor, developed in 1911 as a combination of the famous retractors of Gosset and Doyen. ${ }^{12,13}$ The retractor (Fig. 4) consists of two broad, curved-outward blades and a central

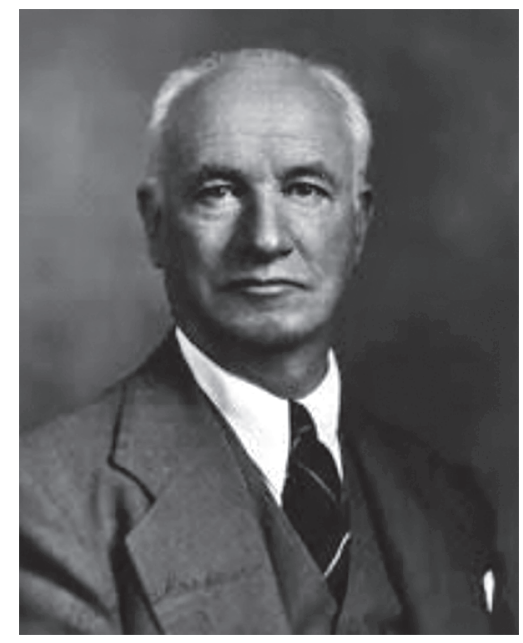

Fig. 3: Donald Balfour

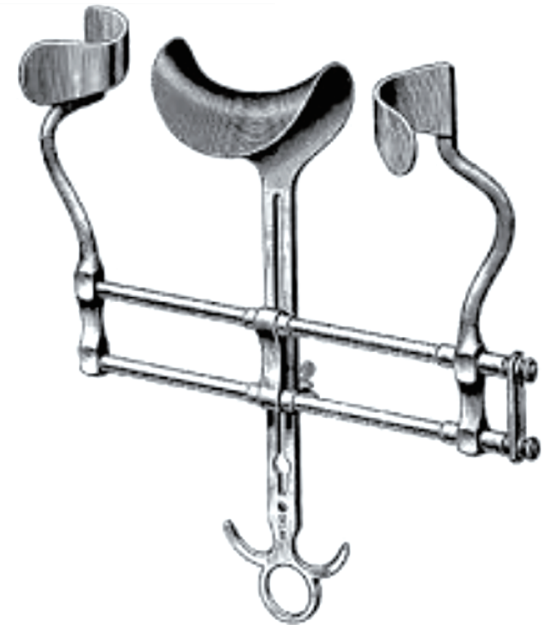

Fig. 4: The Balfour retractor 
retractor blade that are mounted on a ratcheted bar. The blades can be pushed apart to open the incision and the ratcheting device holds them in place. The central blade can be raised or lowered to increase the view of the surgical field, as needed. It is the most widely used retractor in laparotomies, providing excellent exposure of the abdomen as well as pelvis. It was also modified for retropubic operations. $^{14}$

Balfour was born in Toronto and graduated from The University of Toronto Medical School in 1906.11,12,15-19 He joined the Mayo Clinic in 1907 as a pathology assistant. By 1912, he became the division head of general surgery. He was skilled in gastrointestinal surgery and remarkably, performed more than 200 surgeries without a death. In addition to the famous retractor, he also invented operating tables and operating room mirrors, and a stent to perform an anastomosis between parts of the large bowel. ${ }^{18} \mathrm{He}$ retired from active surgery in 1933 due to tuberculosis and was appointed associate director of the Mayo Foundation for Medical Education and Research in 1935. He served as the director from 1937 to $1947 .^{16}$

Balfour authored 225 publications and co-authored a textbook titled The Stomach and Duodenum in $1935 .{ }^{14-19}$ He retired from the Mayo Clinic and Mayo Foundation in 1947 and died in Rochester in 1963 from pulmonary edema caused by myocardial infarction.

Balfour received many honors. ${ }^{12,14-19}$ He was awarded the President's Certificate of Merit in 1948 by President Harry S. Truman for his leadership in training over 1,500 medical officers of the armed forces. ${ }^{11}$ He received the American Medical Association's Distinguished Service Award in $1955^{20}$ and the American Gastroenterological Association's Friedenwald Medal in 1956. He served as president of the American College of Surgeons. He was a co-founder of the American Board of Surgery. ${ }^{11} \mathrm{He}$ was a founding member of the World Medical Association. ${ }^{11}$ He was a charter member of the World Health Organization. He was an honorary fellow of various international surgical colleges of England, Edinburgh, Australasia, and Canada. He received honorary degrees from many universities and became emeritus professor of surgery at the Mayo Foundation. ${ }^{11,14-20}$

In 1910, he married Carrie Mayo, ${ }^{20,21}$ daughter of William J. Mayo, who presented him with a house as a wedding gift. He and Carrie lived in the house until 1960 and donated it to the Mayo Foundation. The couple also was interested in farming. Balfour was a talented pianist and organist.

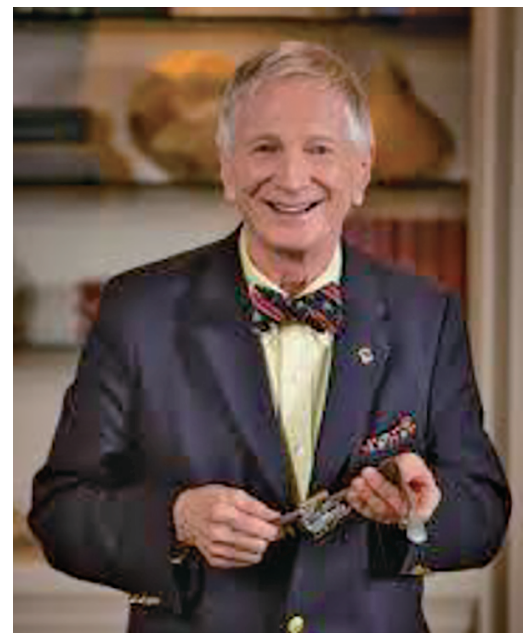

Fig. 5: John Bookwalter
After a long battle with cancer, Carrie died in 1960. Balfour died of a heart attack in 1963 at the age of $81 .{ }^{21}$

\section{JOHN BOOKWALter ${ }^{23-27}$}

The Bookwalter retractor (Figs 5 and 6 ) is the latest and the most used self-retaining retractor today. ${ }^{23}$ It is being updated frequently with improvements to its components: the post, ratchet, and rings.

John R. Bookwalter was born in Columbiana, Ohio to a doctor and a nurse. His grandfather was also a doctor. One day, while on house calls, his father told him: "It is a privilege to take care of sick people". ${ }^{26}$ Bookwalter graduated from Harvard Medical School in 1964 and went on to finish a surgical residency in a Boston City Hospital in 1970. He served in the army for 2 years and then completed a cardiothoracic fellowship at Deaconess Hospital. Subsequently, he rejoined the Army Reserves, ultimately achieving the rank of full Colonel. He was in private practice in Brattleboro, Vermont from 1973 till his retirement in 2012. Even after retiring, Dr Bookwalter is committed to inspiring new ideas and innovations. ${ }^{23-27}$

The initial motivation and the idea of a self-retaining retractor were born when he was a medical student. ${ }^{23}$ As a junior assistant, he loathed the idea of hanging on to a retractor at the operating table, half-asleep and not able to see much of the operation. He aspired to improve the safety and efficacy of abdominal and pelvic surgery and enhance the learning environment for students and trainees. When he was at Fort Bragg for his army rotation, he had the time to focus on improving the existing Smith retractor ${ }^{24}$ which was based on a two-point fixation of the retractor to the operating table. The result was his modification to a single point of fixation of the ring. ${ }^{25}$ It allowed the surgeon flexibility to rotate it as he needed to change the field of interest. Other advantages of the retractor soon became apparent ${ }^{23}$ : the ability of the surgeon to fix it to the operating table after prepping and draping the sterile field, allowing repositioning the retractor in the middle of a surgical procedure; the ratchet system was easy in moving and repositioning of retractor blades much to the delight of the surgeons. A variety of retractor blades were available as needed and provided excellent exposure.

Bookwalter patented his retractor in 1979 and described it in 1980. ${ }^{25}$ Very rapidly, it received national and international acclaim. Currently, the retractor is used all over the world. It is a particular favorite of community surgical practice where surgical students

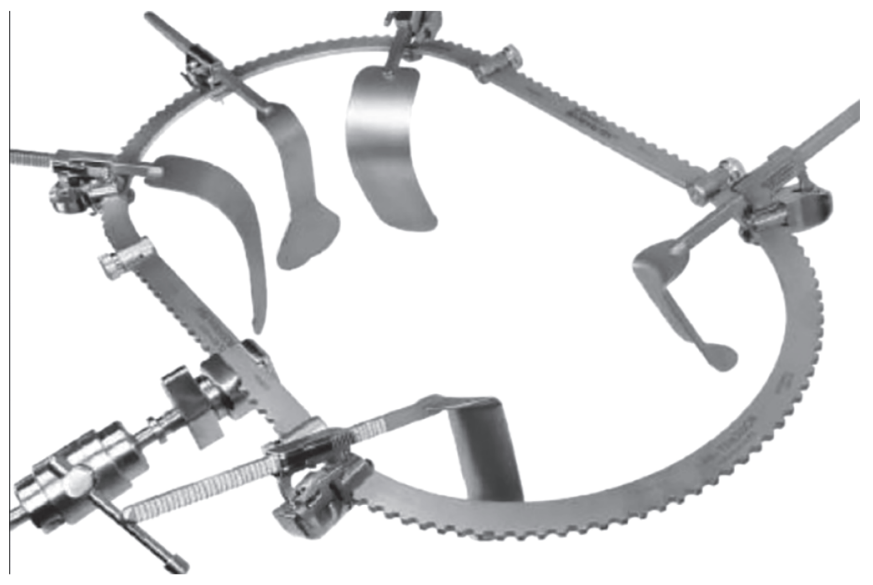

Fig. 6: The Bookwalter retractor 
and residents are in short supply as surgical assistants. Even in teaching hospitals, it is seen as an important tool to facilitate resident education, allowing them excellent visualization and participation. It transcends specialty lines from general surgery to urology and transplant surgery. Transplant surgeons found that it reduced the need for thoracoabdominal incisions. ${ }^{23-27}$ Marina, from the Mayo Clinic, described a modification of the Bookwalter for vaginal surgery. ${ }^{28}$ It was even found useful in the era of COVID to avoid aerosolization of the virus during tracheostomy. ${ }^{29}$

Bookwalter attributes his success to being in the right place at the right time and "a commitment to try to make it better based on feedback, continuous improvement with backwards compatibility". ${ }^{23,25,27} \mathrm{He}$ has lived up to this statement by constant modification and improvement of his retractor.

Bookwalter received many honors, including the Distinguished Service Award from the Vermont Medical Society in 2013 and the highest honor from Newsworthy Publishing as one of their Top 101 Outstanding Professionals of 2017. ${ }^{23,25-27}$ This writer proudly and fondly recalls the opportunity he had, as a young surgeon, of spending some time with this legend in early 1995.

In summary, these are the exemplary lives and accomplishments of inventors that assist us every day in our surgical procedures. Young surgeons do well to learn about these legends and ruminate on their words:

"Only the surgeon who goes beyond his obligations serves his duty" (Finochietto); 5

"....in the study of disease thorough and accurate observation is the first requirement" (Balfour); ${ }^{22}$

"The opportunity for improvement comes from something that is difficult" (Bookwalter). ${ }^{27}$

\section{References}

1. Ailawadi G, Alykhan S, Nagji AS, et al. The legends behind cardiothoracic surgical instruments. Ann Thorac Surg 2010;89(5):16931700. DOI: 10.1016/j.athoracsur.2009.11.019.

2. Enrique Finochietto - Wikipedia https://en.wikipedia.org 'wiki accessed 12/22/2020.

3. Deysine M. Enrique and ricardo finochietto: surgery, the ultimate devotion. Surgery 1973;73:490-499.

4. Varea E. Enrique finochetto (1881-1948). Investig Urol (Berl) 1979;16(4):307-308.

5. de la Fuente SL. Enrique finochietto: the legacy of surgery in Argentina. J Surg Educat 2007;64(2):120-123. DOI: 10.1016/j. jsurg.2006.12.003.

6. Buzzi A, Enrique finochietto: cirujano, docente, investigador e inventor. htttp://www.almarevista.com > accessed 12/9/2020.

7. Hugo E. Alejandro posadas, argentinian pioneer: thoracic surgery in the Western World in his time. Ann Thorac Surg 2004;78(2):741-745. DOI: 10.1016/j.athoracsur.2003.12.049.
8. Fairman D. Obituaries; professor enrique finochietto, 1881-1948. Dis Chest 1948;14(3):472-474. DOI: 10.1016/S0096-0217(15)30789-5.

9. DeBakey M. Professor enrique finochietto, 1881-1948. Ann Surg 1948;128(2):319-320. DOI: 10.1097/00000658-19480800000015.

10. Buen_amigo_(tango) https://es.wikipedia.org/wiki/. Accessed $12 / 25 / 2020$.

11. http://www.recoletacemetery.com: 435 . burgos y colón - After Life - Recoleta Cemetery accessed 12/24/2020.

12. https://en.wikipedia.org > Donald Balfour - accessed 12/20/2020.

13. Balfour D. A combination abdominal retractor. Ann Surg 1912;55(3):419-420. DOI: 10.1097/00000658-191203000-00010.

14. Tara HH. Modification of the Balfour retractor for retropubic operations. J Urol 1967;98(6):716-717. DOI: 10.1016/S00225347(17)62963-X.

15. Keys TE. Donald C. Balfour, 1882-1963. Bull Med Libr Assoc 1963;51(4):617-618.

16. Clark NW. Historical profiles of mayo. Mayo Clin Proc 1963;68(10):938. DOI: 10.1016/S0025-6196(12)62264-2.

17. Eusterman GB. Sr. Donald Church Balfour 1882-1963. Gastroenterology 1964;46(2):207-208. DOI: 10.1016/S0016-5085(64)80060-3.

18. Corman ML. Donald Church Balfour 1882-1963. Dis Colon Rectum 1984;27(8):559-562. DOI: 10.1007/BF02555529 Br Med J 1962;2(5321):1750.

19. A Biography of DC Balfour. Rochester Post-Bulletin. July 26, 1963. https://link.springer.com.

20. BenM.Dr.DonaldC.Balfourawarded distinguishedservicemedal.JAMA 1955;158(7):567. DOI: 10.1001/jama.1955.02960070043013https:// pubmed.ncbi.nlm.nih.gov.: accessed 12/10/2020.

21. Clio: Your Guide to History. January 27, 2020. https://www.theclio. com/entry/94038 Accessed December 26, 2020.

22. Balfour DC, Keys TE. A stained glass window on the history of medicine. Bull Med Libr Assoc 1944;32(4):488-495.

23. Barr J, Brayman KL. Development and evolution of self-retaining retractors in surgery: the example of the bookwalter retractor. J Am Coll Surg 2015;221(2):628-634. DOI: 10.1016/j.jamcollsurg.2015. 03.048 .

24. Smith D. An anchored mechanical retractor. Am J Surg 1952;83(5):717720. DOI: 10.1016/0002-9610(52)90309-7.

25. Bookwalter J. A new table-fixed retractor. Surg Clin North Am 1980;60(2):399-405. DOI: 10.1016/S0039-6109(16)42088-8.

26. Alumni spotlight: John Bookwalter, MD, FACS, 1970. INSIDE SURGERY - Beth Israel Deaconess Medical Center, Fall/Winter 2019; 9,3: 6-http://www.bidmc.org > files > beth-israel-org > surgery. Accessed 12/18/20.

27. Kim P. Surgical entrepreneurism: an interview with the inventor of the bookwalter retractor. Gen Surg 2013;30, Accessed 12/12/2020.

28. Magrina J. Self-retaining retractor for vaginal operations. J Gynecol Surg 1991;7(1):33. DOI: 10.1089/gyn.1991.7.33.

29. Yarlagadda BB, Anderson T. Use of bookwalter retractor to create a working space for tracheostomy during the coronavirus. JAMA Otolaryngol Head Neck Surg 2020. Published online October 8, 2020 E1. https://jamanetwork.com/ on 12/19/2020. 